\title{
A 2-year-old child with dorsal dermal sinus presenting with sudden onset of inability to stand
}

\author{
Dhilip Andrew 지 , Karthik Shyam ำ , Jovis Johny
}

Radiology, St John's Medical College Hospital, Bangalore, Karnataka, India

\section{Correspondence to} Dr Karthik Shyam; dr.karthikshyam@gmail.com

Accepted 9 January 2021
Check for updates

(c) BMJ Publishing Group Limited 2021. No commercial re-use. See rights and permissions. Published by BMJ.

To cite: Andrew $D$, Shyam K, Johny J. BMJ Case Rep 2021:14:e239284. doi:10.1136/bcr-2020239284

\section{DESCRIPTION}

A 2-year-old child presented to the paediatric emergency department with sudden onset of inability to stand unsupported for 1 week. The parents noticed a discharging sinus in posterior aspect of lower neck at 2 months of age, which had discharged pus 2 months ago, with associated fever and pain. At presentation, there was no discharge or fever. On examination, the child was afebrile with stable vitals. Local examination revealed a midline sinus opening over the upper dorsal spine. No discharge or erythema was seen.

Contrast-enhanced MRI of the spine was performed. Precontrast images demonstrate

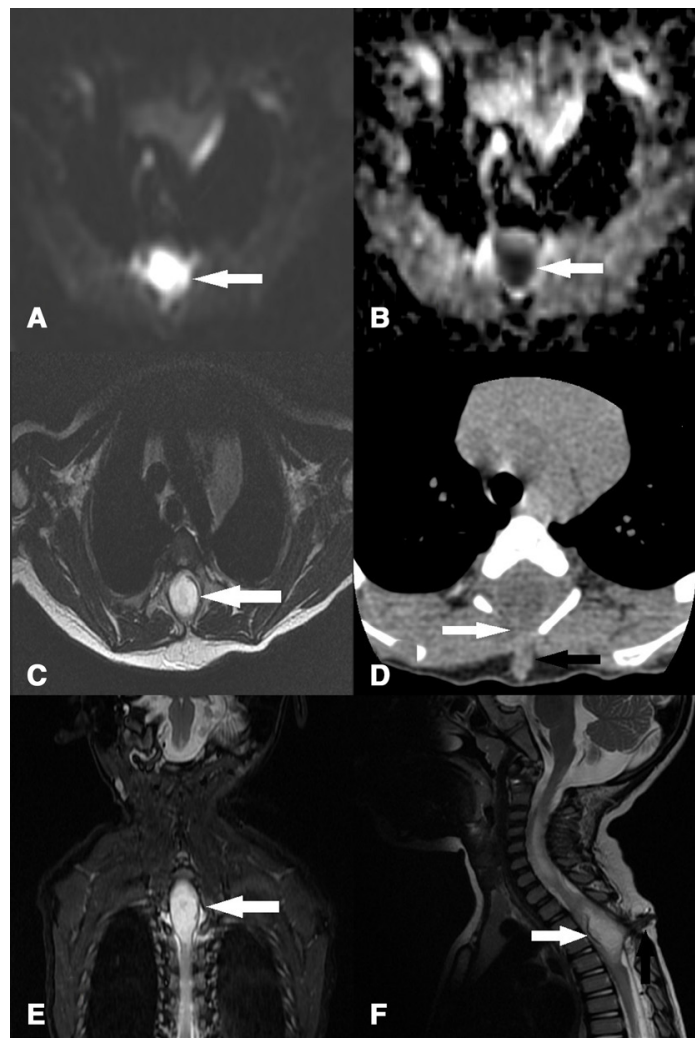

Figure 1 A, B: Diffusion Weighted Image (DWI) and Apparent Diffusion Coefficient (ADC) images at the level of lesion demonstrating diffusion restriction (white arrow). C: T2-weighted image demonstrating T2 hyperintense intramedullary lesion. D: CT image at the level of D4 vertebra demonstrating absent posterior process of the vertebra (white arrow) and sinus tract (black arrow). E, F: Coronal and sagittal T2-weighted images demonstrating intramedullary hyperintense lesion at the level of D3-D5 vertebrae (white arrow).

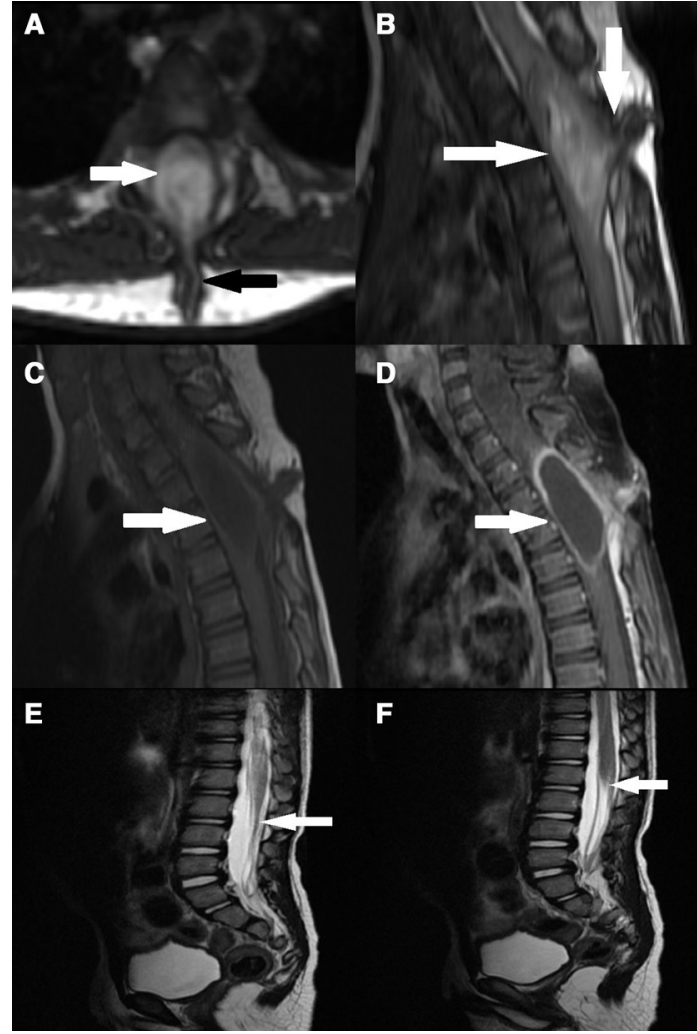

Figure 2 A, B: Axial and coronal Fast Imaging Employing Steady-sTate Acquisition (FIESTA) images demonstrating hyperintense intramedullary lesion (white arrow) and sinus tract (black arrow). C, D: Sagittal T1 precontrast and postcontrast images demonstrating peripherally enhancing $\mathrm{T} 1$ hypointense intramedullary lesion. E, F: Sagittal T2-weighted images demonstrating thickened filum terminale (white arrows) - S/o tethered cord.

intramedullary T2 hyperintense lesion with diffusion restriction and perilesional oedema at D3-D6 (figure 1A-F). A dorsal dermal sinus tract communicating with the spinal canal was noted at D4 level (figure 2A,B). Lesion showed rim enhancement (figure 2C,D) on postcontrast images. Tethered cord (figure 2E,F) was also noted. CT of dorsal spine revealed absent posterior vertebral process of D3-D5 vertebrae (figure 1D). Radiological diagnosis of intramedullary abscess was made. The child underwent myelotomy with drainage of abscess, excision of the lesion and dermal sinus with untethering of cord. Intraoperatively, diagnosis of infected dermoid sinus was made, and the same was confirmed by histopathological examination. 
Dermal sinus is caused by failure of cleavage of cutaneous ectoderm from neuroectoderm; they can be potential route for infection. ${ }^{1}$ Dermal sinus accounts for $48 \%$ of intramedullary abscess in paediatric population. ${ }^{2} 3$ The inner end of the dermal sinus can expand and give rise to dermoid or epidermoid tumour ${ }^{1}$; epidermoid tumours occur more often than dermoid, but dermal sinus is more frequently associated with dermoid. ${ }^{45}$

Intraspinal dermoid cyst accounts for $0.8 \%-1.1 \%$ of intraspinal tumours. They commonly occur in the lumbosacral region and may or may not be associated with spinal dysraphism. ${ }^{6}$ Dermoid cyst contains dermal and epidermal derivatives; they arise from totipotent ectodermal cells. ${ }^{7}$ Infected dermoid cyst is a rare cause of intramedullary abscess and can be caused by contiguous spread of infection via dermal sinus. ${ }^{23}$ On MRI, dermoid cyst has heterogenous appearance depending on the content of the cyst. ${ }^{8}$ Fat content within the cyst can appear hyperintense on T1-weighted image and as a low attenuation lesion on CT. ${ }^{9}$ The dermal sinus will appear as T1 hypointense tract from the skin to intramedullary region through a defect in posterior element. Infected dermoid cyst has a heterogenous appearance; however, they usually present as a mass causing expansion of cord with perilesional oedema. On postcontrast MRI, there is rim enhancement with features of solid component and septations. $^{10}$

Treatment of choice is excision of dermal sinus with drainage of abscess through a dorsal midline myelotomy at the site of maximum swelling and fluctuation followed by excision of lesion. ${ }^{11}$ Non-infected dermoid has excellent prognosis, and in case of infected dermoid cyst, only $20 \%$ of case could recover completely. ${ }^{2} 1213$ Hence, early diagnosis

Learning points

- Dermoid sinus more often presents with dorsal dermal sinus.

- Dorsal dermal sinus can act as pathways for infection leading to formation of intramedullary abscess.

- Common location for dermoid cyst is the lumbosacral region. and prompt surgical management of intramedullary abscess are required to prevent complications.

Contributors DA, KS and JJ have equally contributed to procurement of images, interpretation and clinical follow-up. DA drafted the manuscript; KS and JJ have edited and finalised the draft.

Funding The authors have not declared a specific grant for this research from any funding agency in the public, commercial or not-for-profit sectors.

Competing interests None declared.

Patient consent for publication Obtained.

Provenance and peer review Not commissioned; externally peer reviewed.

\section{ORCID iDs}

Dhilip Andrew http://orcid.org/0000-0002-6154-3063

Karthik Shyam http://orcid.org/0000-0003-0998-9604

\section{REFERENCES}

1 Morandi X, Mercier P, Fournier H-D, et al. Dermal sinus and intramedullary spinal cord abscess. Child's Nervous System 1999;15:202-7.

2 Chan CT, Gold WL. Intramedullary abscess of the spinal cord in the antibiotic era: clinical features, microbial etiologies, trends in pathogenesis, and outcomes. Clin Infect Dis 1998;27:619-26.

3 Simon JK, Lazareff JA, Diament MJ, et al. Intramedullary abscess of the spinal cord in children: a case report and review of the literature. Pediatr Infect Dis J 2003:22:186-92.

4 Shikata J, Yamamuro T, Mikawa Y, et al. Intraspinal epidermoid and dermoid cysts. surgical results of seven cases. Arch Orthop Trauma Surg 1988;107:105-9.

5 Baxter JW, Netsky MG. Epidermoid and dermoid tumors. In: Wilkins RH, Renchagary SS, eds. Neurosurgery. New York: McGraw-Hill, 1985: 1. 655-61.

6 Falavigna A, Righesso 0, Teles AR. Concomitant dermoid cysts of Conus medullaris and cauda equina. Arq Neuropsiquiatr 2009;67:293-6.

7 Pant I, Joshi SC. Cerebellar intra-axial dermoid cyst: a case of unusual location. Childs Nerv Syst 2008;24:157-9.

8 McAdams HPet al. Mediastinum. In: Haaga JR, ed. Ct and MR imaging of the whole body. . 4th edn, 1994: 1. 959-60.

9 Cha JG, Paik S-H, Park J-S, et al. Ruptured spinal dermoid cyst with disseminated intracranial fat droplets. Br J Radiol 2006;79:167-9.

10 Girishan S, Rajshekhar V. Rapid-Onset paraparesis and quadriparesis in patients with intramedullary spinal dermoid cysts: report of 10 cases. J Neurosurg Pediatr 2016;17:86-93.

11 Vadivelu S, Desai SK, Illner A, et al. Infected lumbar dermoid cyst mimicking intramedullary spinal cord tumor: observations and outcomes. J Pediatr Neurosci 2014;9:21

12 Murphy KJ, Brunberg JA, Quint DJ, et al. Spinal cord infection: myelitis and abscess formation. AJNR Am J Neuroradiol 1998;19:341-8.

13 Tufan K, Cekinmez M, Sener L, et al. Infected lumbar dermoid cyst presenting with tetraparesis secondary to holocord central lesion. J Child Neurol 2008;23:934-7.

Copyright 2021 BMJ Publishing Group. All rights reserved. For permission to reuse any of this content visit

https://www.bmj.com/company/products-services/rights-and-licensing/permissions/

BMJ Case Report Fellows may re-use this article for personal use and teaching without any further permission.

Become a Fellow of BMJ Case Reports today and you can:

- Submit as many cases as you like

- Enjoy fast sympathetic peer review and rapid publication of accepted articles

- Access all the published articles

Re-use any of the published material for personal use and teaching without further permission

Customer Service

If you have any further queries about your subscription, please contact our customer services team on +44 (0) 2071111105 or via email at support@bmj.com.

Visit casereports.bmj.com for more articles like this and to become a Fellow 